\title{
RANCANG BANGUN PERANGKAT SISTEM PANGGIL PERAWAT (NURSE CALL) BERBASIS MIKROKONTROLER ATMEGA8535-DENGAN FITUR KOMUNIKASI
}

\section{NURSE CALL SYSTEM DESIGN AND DEVELOPMENT BASED ON MICROCONTROLLER ATMEGA8535-WITH COMMUNICATION FEATURE}

\author{
Djoko Nursanto*, Pria Sukamto, Arif Eko Wicaksono \\ ${ }^{*}$ Program Studi Teknik Informatika, Sekolah Tinggi Teknologi Muhammadiyah Cileungsi \\ * Jln. Anggrek No.25 Komplek Perum PTSC, Cileungsi, Bogor, Jawa Barat-Indonesia 16820
}

\section{Informasi Artikel \\ Article History: \\ Submission: 1105/2021 \\ Revised: 07/05/2021 \\ Accepted: 15/06/2021}

\section{Kata Kunci:}

Sistem panggil perawat; digital; mikrokontroler; atmega8535; fitur komunikasi.

\section{Keywords:}

Nurse Call System; digital; microcontroller; Atmega8535; communication feature.

\section{* Korespondensi:}

Djoko Nursanto djokonursanto@sttmcileungsi.ac.id

\begin{abstract}
Abstrak
Perangkat sistem pemanggil perawat atau biasa disebut nurse call, wajib dimiliki oleh sebuah rumah sakit. Perangkat ini berada di ruang perawatan-inap pasien. Fungsi perangkat ini adalah untuk memanggil perawat yang berada di pos perawat apabila seorang pasien membutuhkan bantuan. Tombol panggil ada disamping tempat tidur pasien dan di kamar mandi. Dalam pedoman teknis yang diterbitkan oleh Departemen Kesehatan disebutkan bahwa perangkat nurse call harus memiliki kemampuan komunikasi audio antara perawat dan pasien akan tetapi ternyata tidak semua perangkat nurse call di rumah sakit memiliki memiliki fitur ini. Perangkat nurse call dengan fitur komunikasi biasanya harganya jauh lebih mahal. Tujuan penelitian yaitu membuat rancang bangun Perangkat Sistem Pemanggil Perawat menggunakan Mikrokontroler ATmega8535 sebagai pengendali utama. Rancangan yang dibuat diharapkan bisa memberikan alternatif penyediaan sistem pemanggil perawat/nurse call yang lebih ekonomis tetapi tetap efektif, efisien, dan mudah dalam perawatan. Penggunaan mikrokontroler dan komponen elektronika digital tanpa memakai komputer sebagai pengendali, membuat harga jauh lebih murah dan konsumsi daya listrik sangat kecil. Fitur komunikasi yang dimiliki oleh perangkat nurse call juga akan meningkatkan waktu tanggap dan menghemat tenaga kesehatan yang sedang bertugas di ruang rawat inap.
\end{abstract}


effective, efficient, and easy to care for. The use of microcontrollers and digital electronic components without using a computer as a controller, makes the price much cheaper and the electrical power consumption is very small. The communication feature owned by the nurse call device will also increase response time and save health workers who are on duty in the hospital room.

\section{PENDAHULUAN.}

Keberadaan perangkat SPP di rumah sakit diatur dengan regulasi pemerintah berupa Undang-Undang, Keputusan Menteri, dan petunjuk pelaksanaan teknis lainnya. Undang Undang No 44 tahun 2009 tentang Rumah Sakit [2]. Pedoman Teknis Fasilitas Rumah Sakit, yang diterbitkan oleh Pusat Sarana Prasarana dan Peralatan Kesehatan, Sekretariat Jenderal Kementerian Kesehatan RI tahun 2010.

Perangkat SPP digunakan pasien untuk memanggil perawat di pos perawat (nurse station). Selain itu perangkat ini juga bisa digunakan sebagai sarana komunikasi dua arah antara perawat dan pasien [1]. Dalam perancangan perangkat sistem panggil perawat (Nurse Call) mengacu pada kete. ntuan Pedoman Teknis Fasilitas Rumah Sakit Kelas B, yang diterbitkan oleh Pusat Sarana Prasarana dan Peralatan Kesehatan, Sekretariat Jenderal Kementerian Kesehatan Republik Indonesia, tahun 2010.

Tabel 1. Hasil survei perangkat SPP di beberapa rumah sakit.

\begin{tabular}{|c|c|c|c|}
\hline No. & Nama Rumah Sakit & SPP & Fitur Komunikasi \\
\hline 1. & Rumah Sakit Meilia Cibubur & $\sqrt{ }$ & $\mathrm{X}$ \\
\hline 2. & Rumah Sakit Mary Cileungsi & $\sqrt{ }$ & $\mathrm{X}$ \\
\hline 3. & Rumah Sakit MH Thamrin Cileungsi & $\sqrt{ }$ & $\mathrm{X}$ \\
\hline 4. & Rumah Sakit Ibu dan Anak Kenari & $\sqrt{ }$ & $\mathrm{X}$ \\
\hline 5. & Rumah Sakit Umum Daerah Kota Bekasi & $\sqrt{ }$ & $\sqrt{ }$ \\
\hline 6. & Rumah Sakit Hermina Cileungsi & $\sqrt{ }$ & $\sqrt{ }$ \\
\hline 7. & Rumah Sakit Permata Bekasi & $\sqrt{ }$ & $\sqrt{ }$ \\
\hline
\end{tabular}

Keterangan: $\sqrt{ }=$ Ada $\quad \mathrm{X}=$ Tidak Ada

Berdasarkan pengamatan penulis, saat ini belum semua rumah sakit memiliki sistem pemanggil perawat (SPP) yang memenuhi standar regulasi yang berlaku. Bagi rumah sakit, untuk mengganti perangkat SPP yang lama dengan SPP dengan teknologi terbaru dibutuhkan investasi yang cukup mahal. Perlu ada sebuah rancang bangun perangkat SPP yang memenuhi ketentuan teknis tetapi dengan biaya yang minimum. Perangkat SPP disusun menggunakan gabungan rangkaian analog dan digital, serta menggunakan mikrokontroler ATmega8535 sebagai pengendali utama.

Berdasarkan pengamatan penulis ketika mengunjungi beberapa rumah sakit diketahui bahwa sebagian besar belum memiliki perangkat SPP yang memiliki fitur komunikasi audio antara pasien dan perawat yang berada di pos perawat. Paling tidak 4 dari 7 rumah sakit yang diamati perangkat SPP yang dimiliki tidak memiliki fitur komunikasi audio ini. 
Tabel 1 adalah data survei yang diambil pada tahun 2015 terhadap sejumlah rumah sakit yang ada di Kabupaten Bogor dan Bekasi. Berdasarkan tabel 1 terlihat bahwa empat dari tujuh rumah sakit yang di survei belum memiliki fitur komunikasi pada perangkat SPP yang mereka miliki. Jadi bisa diambil kesimpulan bahwa sebagian besar rumah sakit belum memiliki fitur SPP yang bisa melakukan komunikasi dua arah antara pasien dengan pos perawat.

Penelitian ini bertujuan membuat rancang bangun perangkat SPP berdasarkan pada Pedoman Teknis Fasilitas Rumah Sakit, yang diterbitkan oleh Pusat Sarana Prasarana dan Peralatan Kesehatan, Sekretariat Jenderal Kementerian Kesehatan RI tahun 2010, bagian V, poin 5.2.2.2. Lokasi penelitian di lakukan di Rumah Sakit Meilia, yang beralamat di Jalan Alternatif Cibubur KM.1, Kelurahan Harjamukti Kecamatan Cimanggis Kota Depok Provinsi Jawa Barat. Sebagai acuan utama dalam pembuatan desain adalah perangkat SPP MedFriend yang digunakan di RS Meilia. Perangkat SPP yang akan dibuat menggunakan gabungan komponen elektronika digital, analog, dan menggunakan pengendali utama mikrokontroler dari keluarga AVR yaitu ATmega8535 [3]. Mikrokontroler dipilih sebagai pengendali utama karena jauh lebih efisien dibanding menggunakan personal computer (PC).

Tujuan penelitian untuk membuat perangkat sistem pemanggil perawat (SPP/Nurse Call) yang memenuhi ketentuan teknis Pedoman Teknis Fasilitas Rumah Sakit, yang diterbitkan sesuai dengan peraturan pemerintah melalui Kementerian Kesehatan RI tahun 2010, bagian V, poin 5.2.2.2. Perangkat SPP dibuat dengan prinsip efektif, efisien, mudah (dalam instalasi, pengoperasian, maupun perawatan), namun berbiaya rendah. Adapun manfaat yang bisa diambil dari penelitian yaitu memberikan sumbangsih ide dalam membuat rancangan perangkat SPP dengan teknologi digital yang menurut penulis saat ini masih sangat sedikit dibahas. Harapannya ide ini bisa terus dikembangkan dengan teknologi dan memiliki kemampuan yang lebih baik lagi.

\section{METODE}

Rancang bangun menurut Kamus Besar Bahasa Indonesia (KBBI) mempunyai arti desain bangunan. Sesungguhnya kata rancang bangun adalah juga merupakan bentukan kata yang berasal dari kata 'merancang' dan 'membangun' [4]. Sehingga rancang bangun bisa diartikan dengan 'merencanakan, menyusun, atau mendirikan sesuatu, tergantung apa obyek yang mengikuti kata selanjutnya. Rancang bangun sangat terkait dengan istilah desain.

\subsection{Desain}

Menurut Alan Dix et all [2]: desain adalah "achieving goals within constraints"-pencapaian suatu tujuan dengan batasan batasan tertentu. Lebih lanjut dikatakan "This does not capture everything about design, but helps to focus us on certain things"- ini tidak menangkap segala sesuatu tentang desain, tetapi membantu memfokuskan kita pada hal-hal tertentu. yaitu:

a. Goal/tujuan difokuskan pada: Apa tujuan dari desain dibuat, siapa yang membutuhkan.

b. Constraint/batasan difokuskan pada: Bahan apa yang digunakan, standar apa yang adopsi, berapa biaya yang dibutuhkan, berapa lama waktu yang diperlukan, faktor apa saja yang mempengaruhi dan perlu dipertimbangkan.

Oleh karena itu dalam membuat desain ada satu hal penting yang disebut trade off, yang dimaksud adalah memilih tujuan atau batasan mana yang bisa dibuat lebih santai asalkan tujuan utama bisa dipenuhi. Alan dix menggambarkan rangkaian proses dalam membuat desain seperti diagram berikut: 


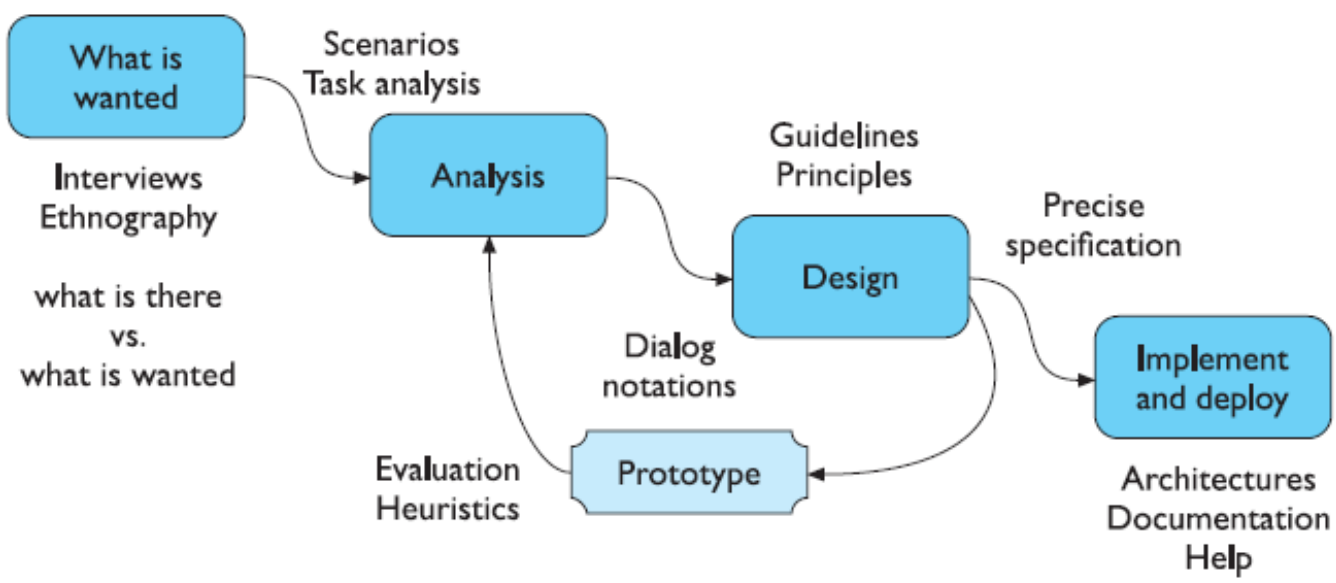

Gambar 1. Diagram air terjun dalam proses pembuatan desain[2]

\subsection{Perangkat sistem pemanggil perawat (SPP)}

Perangkat SPP adalah perangkat sarana komunikasi dua arah antara perawat dan pasien. Sebagaimana dijelaskan pada Pedoman Teknis Fasilitas Rumah Sakit kelas B, tahun 2010, pada bagian $V$ poin 5.2.2.1, dikatakan bahwa:

a) Peralatan sistem pemanggil perawat dimaksudkan untuk memberikan pelayanan kepada pasien yang memerlukan bantuan perawat, baik dalam kondisi rutin atau darurat.

b) Sistem pemanggil perawat bertujuan menjadi alat komunikasi antara perawat dan pasien dalam bentuk visual dan audible (suara), dan memberikan sinyal pada keadaan darurat pasien.

- Perangkat pemanggil biasa diletakkan di samping atau di dekat tempat tidur, panggilan dari tempat ini disebut dengan istilah 'Panggilan Rutin' dan perangkat pemanggil yang diletakkan di kamar mandi pasien, panggilan dari tempat ini disebut 'Panggilan Darurat'.

- Antara panggilan rutin dan darurat dibedakan dari segi tanda visual, suara, dan prosedur perlakuannya, hal ini akan dijelaskan kemudian.

Tabel 2 ketentuan teknis dalam Pedoman Teknis Fasilitas Rumah Sakit kelas B, tahun 2010, pada bagian $\mathrm{V}$ poin 5.2.2.1:

Tabel 2. Ketentuan teknis

\begin{tabular}{|c|c|c|}
\hline NO. & SUB SISTEM & KETENTUAN TEKNIS \\
\hline 1. & $\begin{array}{l}\text { Tombol panggil } \\
\text { pos rutin }\end{array}$ & $\begin{array}{ll}\text { - } & \text { Terletak di dekat tempat tidur pasien } \\
\text { - } & \text { Diaktifkan dengan switch chord. } \\
\text { - Dilengkapi tombol reset } \\
\text { - Dilengkapi modul komunikasi audio (mikrofon dan } \\
\text { speaker) }\end{array}$ \\
\hline 2. & $\begin{array}{l}\text { Tombol panggil } \\
\text { pos darurat }\end{array}$ & $\begin{array}{l}\text { - } \text { Terletak di toilet. } \\
\text { - } \quad \text { Diaktifkan dengan tombol tarik } \\
\text { - } \quad \text { Dilengkapi tombol reset }\end{array}$ \\
\hline 3. & Lampu dome & $\begin{array}{l}\text { - Terdiri dari lampu dengan warna berbeda untuk } \\
\text { menampilkan tanda panggilan rutin, darurat dan nurse } \\
\text { presence. }\end{array}$ \\
\hline 4. & $\begin{array}{l}\text { Modul Room } \\
\text { controller }\end{array}$ & $\begin{array}{l}\text { - Menghubungkan modul rutin, darurat, nurse presence } \\
\text { dan lampu dome. } \\
\text { - Ada modul saklar komunikasi. }\end{array}$ \\
\hline
\end{tabular}


5. Panel Kontrol

6. Sistem komunikasi audio

7. Tombol Nurse Presence
- Dikendalikan oleh panel kontrol,

- Mengendalikan seluruh room controller.

- Menampilkan status ruangan.panggilan pada penampil.

- Memiliki saklar pemilih untuk komunikasi.

- Memiliki alarm audio dengan nada berbeda untuk panggilan rutin dan darurat,

- Menggunakan mikrokontroler Atmega8535 sebagai pengendali utama.

- $\quad$ Penguat mikropon dan penguat daya terletak pada pos rutin dan panel kontrol.

- Hanya bisa diaktifkan melalui panel kontrol.

- Bisa melakukan komunikasi tunggal dan massal.

- Merupakan fitur tambahan yang tidak ada dalam PT Depkes.

- Untuk menunjukkan bahwa perawat telah mendatangi ruangan.

- Modul nurse presence akan reset otomatis apabila seluruh panggilan sudah di reset.

\subsection{Penelitian perangkat SPP di RS Meilia}

Penelitian dilakukan dengan survei secara langsung terhadap perangkat SPP yang ada di RS Meilia untuk mengamati proses dan kemampuan perangkat sebagai bahan referensi. Selain itu juga dilakukan studi literatur terhadap perangkat SPP merk GIRA yang merupakan produk Jerman. Hal yang dipelajari dari SPP GIRA adalah fitur dan kemampuan yang dimiliki.

Dari SPP RS Meilia diperoleh gambaran proses apabila perangkat SPP tidak memiliki fitur komunikasi audio antara pasien dan perawat. Dapat dilihat pada diagram alir pada gambar 2.

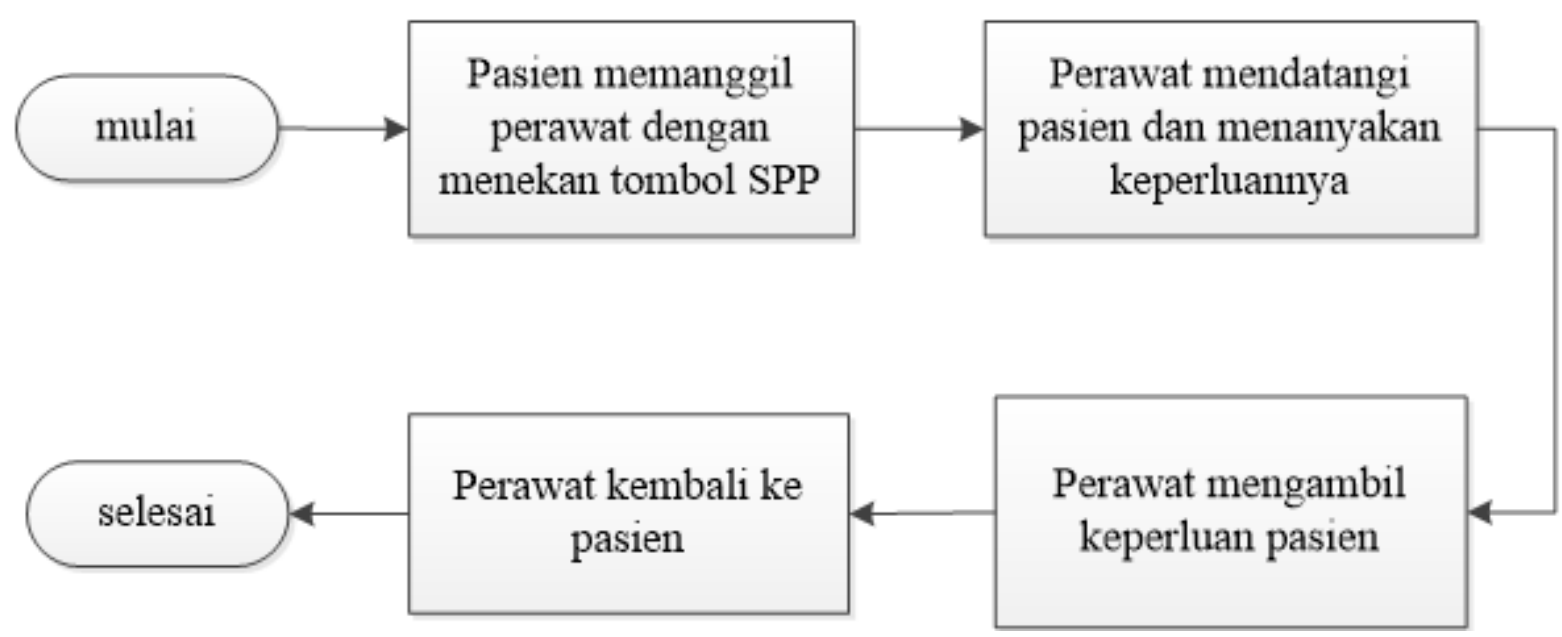

Gambar 2. Diagram alir proses penggunaan perangkat SPP di RS Meilia.

\subsection{Mempelajari SPP GIRA sebagai pembanding}

Dari sisi fitur/kemampuan SPP Medfield dan GIRA [6] memiliki beberapa perbedaan dan persamaan. Apabila dibandingkan dengan kebutuhan yang dipersyaratkan dalam regulasi dapat dilihat pada tabel 3.

Tabel 3. Tabel perbandingan antar perangkat SPP

\begin{tabular}{lllll}
\hline NO. & FITUR/KEMAMPUAN & PT DEPKES & MEDFRIEND & GIRA \\
\hline
\end{tabular}




\begin{tabular}{rlccc}
\hline 1. & Tombol panggil tempat tidur (pos & $\sqrt{ }$ & $\sqrt{ }$ & $\sqrt{ }$ \\
& rutin) & & & \\
2. Tombol tarik di toilet (pos darurat) & $\sqrt{ }$ & $\sqrt{ }$ & $\sqrt{ }$ \\
3. Tombol reset di pos rutin & $\sqrt{ }$ & - & $\sqrt{ }$ \\
4. Tombol reset di pos darurat & $\sqrt{ }$ & $\sqrt{ }$ & $\sqrt{ }$ \\
5. Lampu dome dengan warna berbeda & $\sqrt{ }$ & $\sqrt{ }$ & $\sqrt{ }$ \\
6. Alarm panggilan rutin berbeda darurat & $\sqrt{ }$ & - & $\sqrt{ }$ \\
7. $\quad$ Sistem komunikasi audio & $\sqrt{ }$ & $\sqrt{ }$ \\
8. Tombol Nurse Presence & - & - & $\sqrt{ }$ \\
9. Tombol darurat dokter (code blue) & - & $\sqrt{ }$ & $\sqrt{ }$ \\
10. Terhubung dengan jaringan LAN & - & $\sqrt{ }$ & $\sqrt{ }$ \\
11. Menggunakan PC sebagai panel control & - & & \\
\hline
\end{tabular}

\subsection{Pembuatan desain purwarupa (Prototype)}

Purwarupa adalah terjemahan Bahasa Indonesia dari kata Prototype dalam Bahasa Inggris. KBBI mengartikan 'purwarupa' dengan rupa yang pertama atau awal. Sedangkan 'prototype' menurut Cambridge Dictionary mempunyai arti: the first example of something, such as a machine or other industrial product, from which all later forms are developed: atau contoh yang pertama dari sesuatu, misalnya mesin atau produk industri yang semua bentuknya akan dikembangkan kemudian [7].

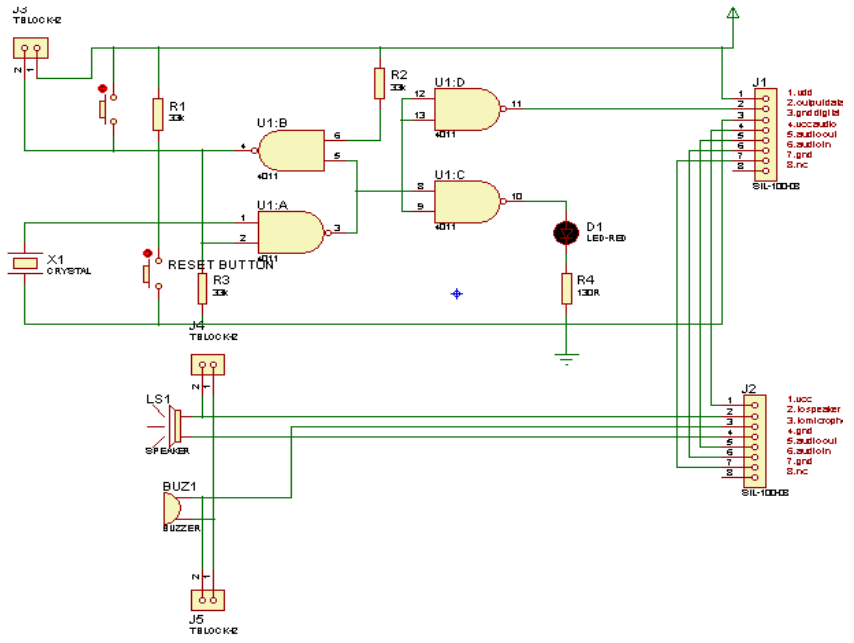

(a)

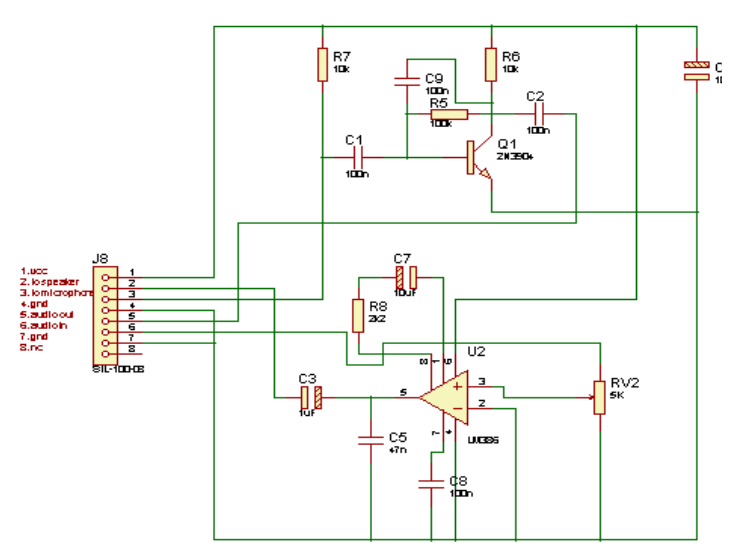

(b)

Gambar 3. Skema rangkaian modul rutin/bedside (a) penguat audio (b)

2.6 Modul yang akan dibuat

Dalam desain perangkat SPP kan dibuat purwarupa dengan skenario perangkat akan digunakan untuk ruang rawat inap sebanyak 5 ruangan dan setiap ruangan terdiri dari satu tempat tidur dan satu kamar mandi. Oleh karena itu sejumlah modul-modul sub sistem yang akan dibuat.
A. Modul rutin/bed
5 set
B. Modul darurat/toilet
5 set
C. Modul nurse presence
5 set
D. Modul room controller
5 set 

E. Lampu dome
5 set
F. Panel kontrol-penampil
5 set
G. Panel kontrol utama
1 set
H. Penguat audio
6 set

2.7 Kebutuhan dalam perancangan

A. Perangkat lunak yang diperlukan:

- Proteus ${ }^{\circledR}$, perangkat lunak ini digunakan untuk merancang skema rangkaian dan PCB (Printed Circuit Board), program aplikasi ini mempunyai kemampuan melakukan simulasi secara virtual untuk mencoba apakah rangkaian bekerja dengan baik atau tidak.

- AVR Studio, perangkat lunak ini digunakan untuk membuat program mikrokontroler, penulis menggunakan bahasa C atau Assembly. AVR Studio juga berfungsi sebagai Compiler untuk mengubah bahasa program menjadi bahasa mesin. [8]

- Extreme Burner-AVR dan Khazama AVR Burner, perangkat lunak Untuk memindahkan program ke keping mikrokontroler (ISP Downloader).

- Corel Draw, program aplikasi ini digunakan untuk membuat desain kemasan.

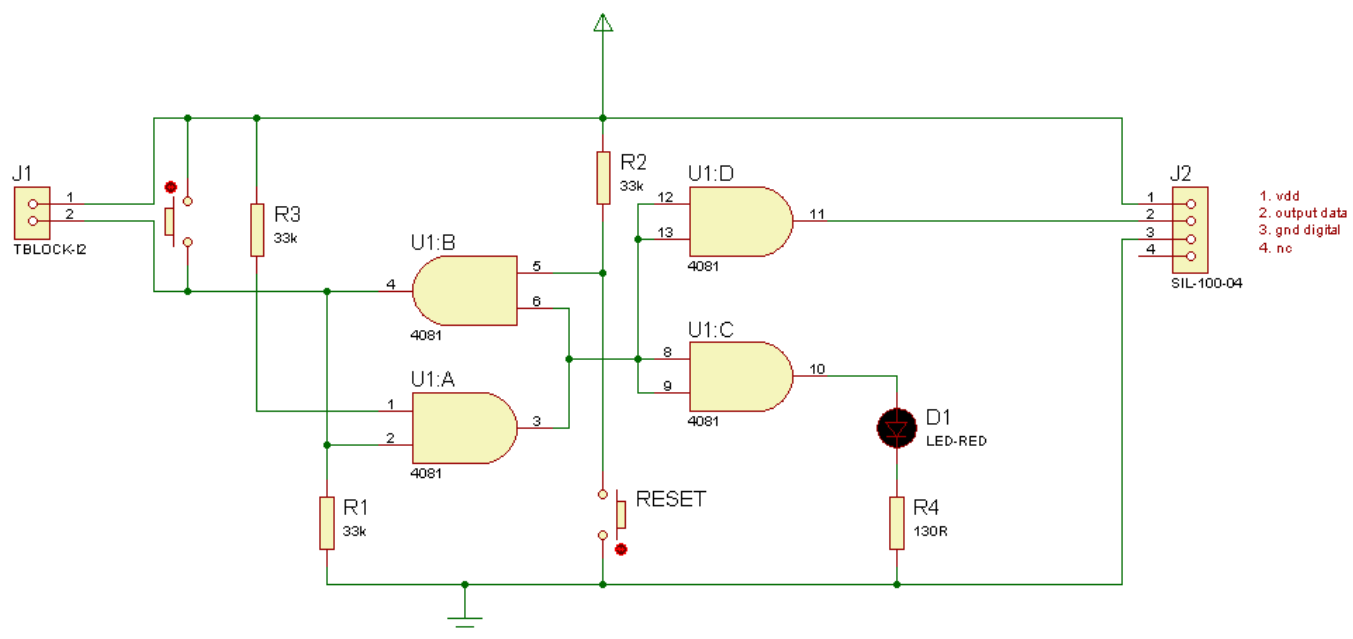

Gambar 4. Modul toilet

B. Perangkat keras yang diperlukan:

- Komputer/Laptop, digunakan untuk membuat skema rancangan, PCB, dan membuat program untuk mikrokontroler.

- Sistem minimum mikrokontroler, digunakan untuk download program kedalam mikrokontroler dan melakukan uji coba input-output.

- USB ISP/ASP Downloader, sebagai antar muka penghubung antara komputer dengan mikrokontroler ketika melakukan download program.

- Papan percobaan, digunakan untuk uji coba rangkaian untuk memastikan rancangan bekerja dengan baik sebelum dibuatkan PCB.

- Printer laser jet atau mesin fotokopi dengan tinta tipe bubuk.

- Komponen-komponen elektronika digital, analog, mikrokontroler ATmega8535, Attiny13 dan lain-lain.

- $\quad$ PCB polos dan $\mathrm{FeCl}$, digunakan untuk membuat PCB. 
- Dan lain-lain

2.8 Skema rancangan modul.

Rancangan modul menggunakan komponen digital dan analog dengan memilih tipe komponen yang mudah diperoleh di pasaran, sehingga akan memudahkan apabila kelak terjadi kerusakan pada komponen.

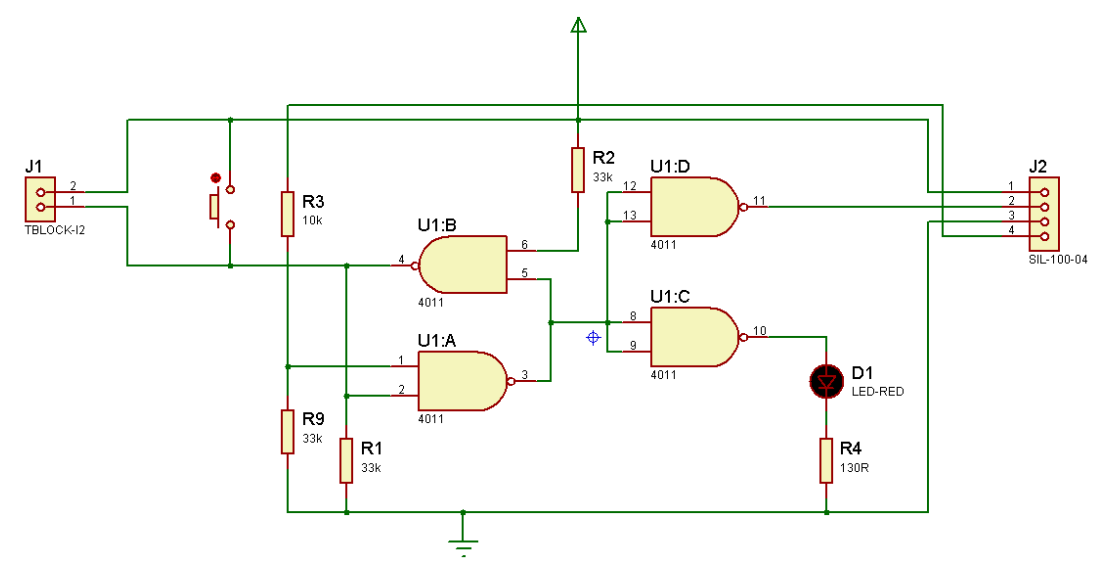

Gambar 5. Modul nurse presence.

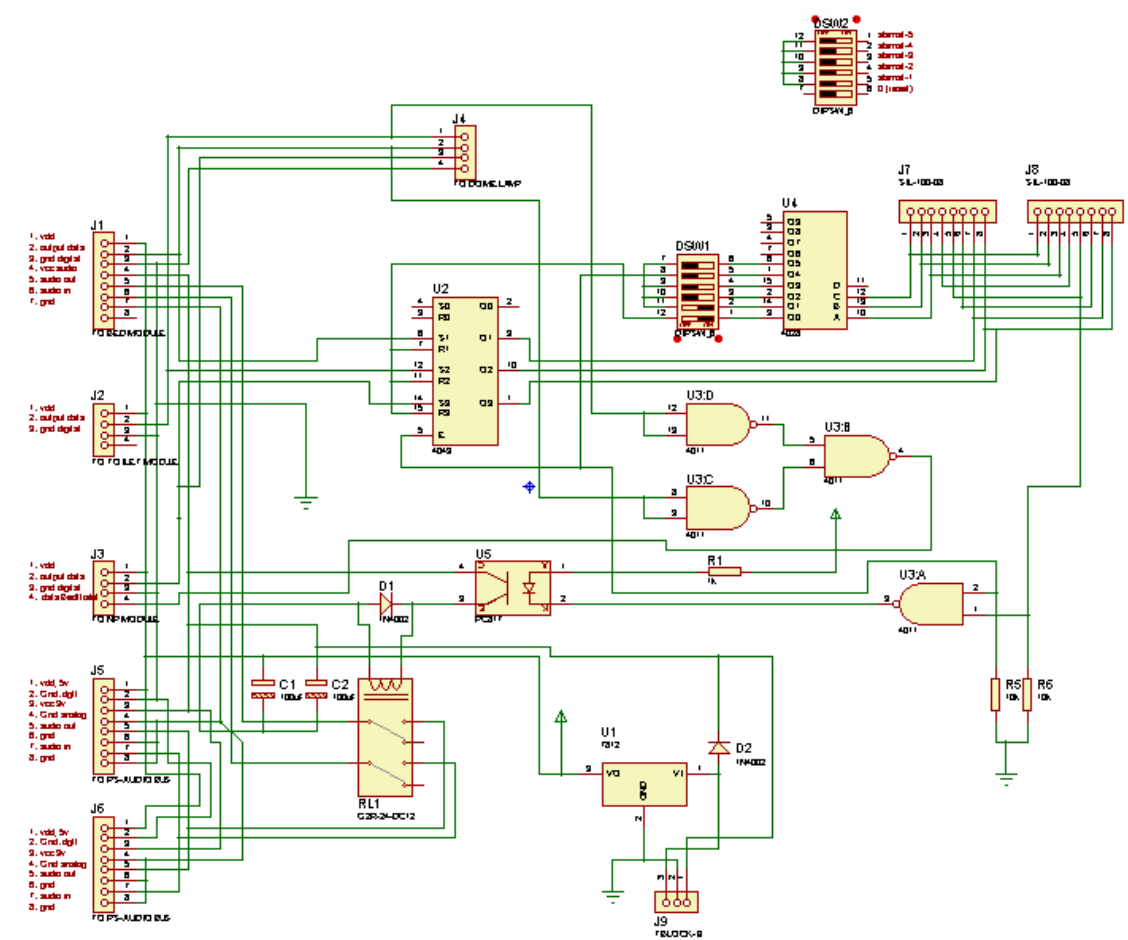

Gambar 6. Modul room controller 


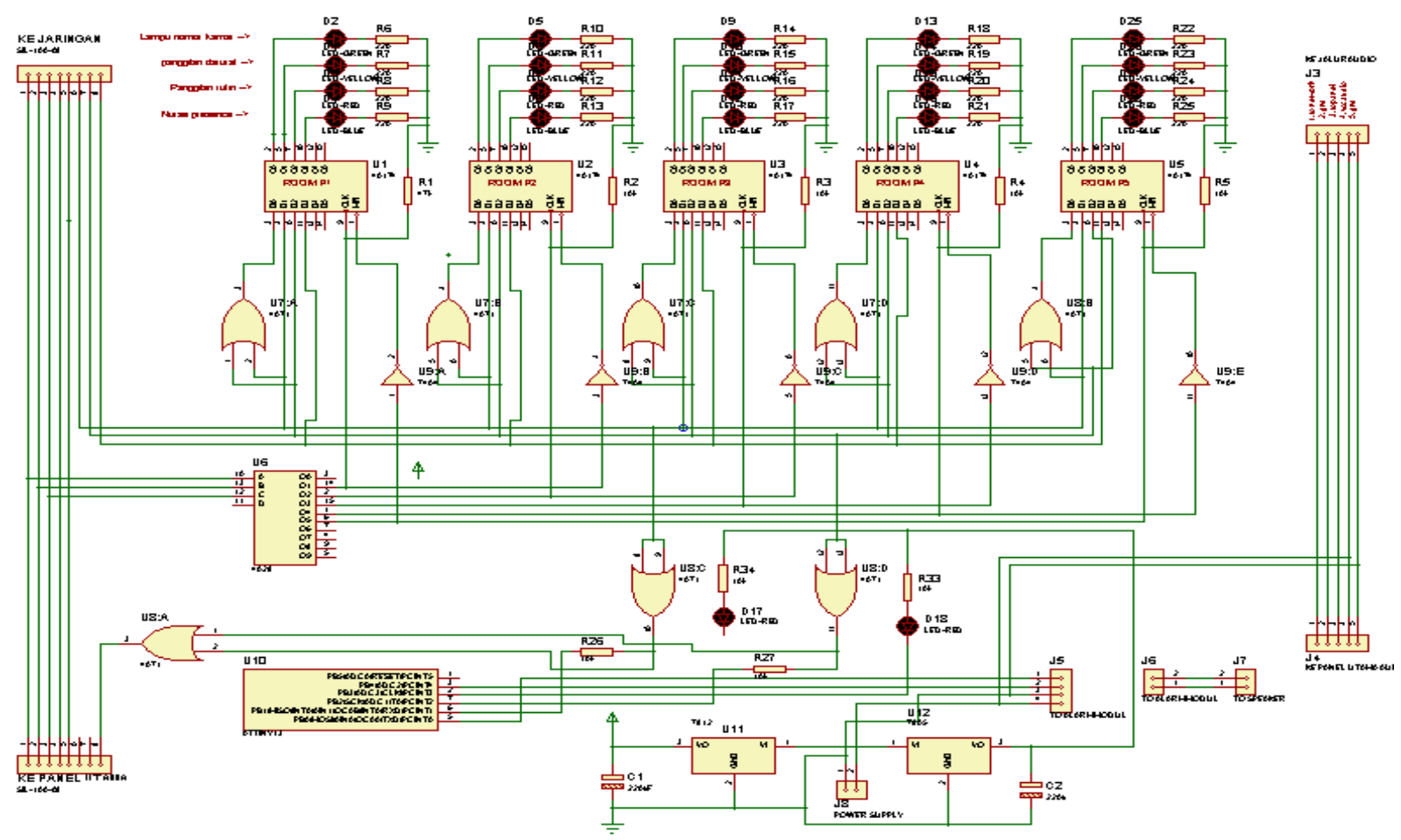

Gambar 7. Modul penampil/display

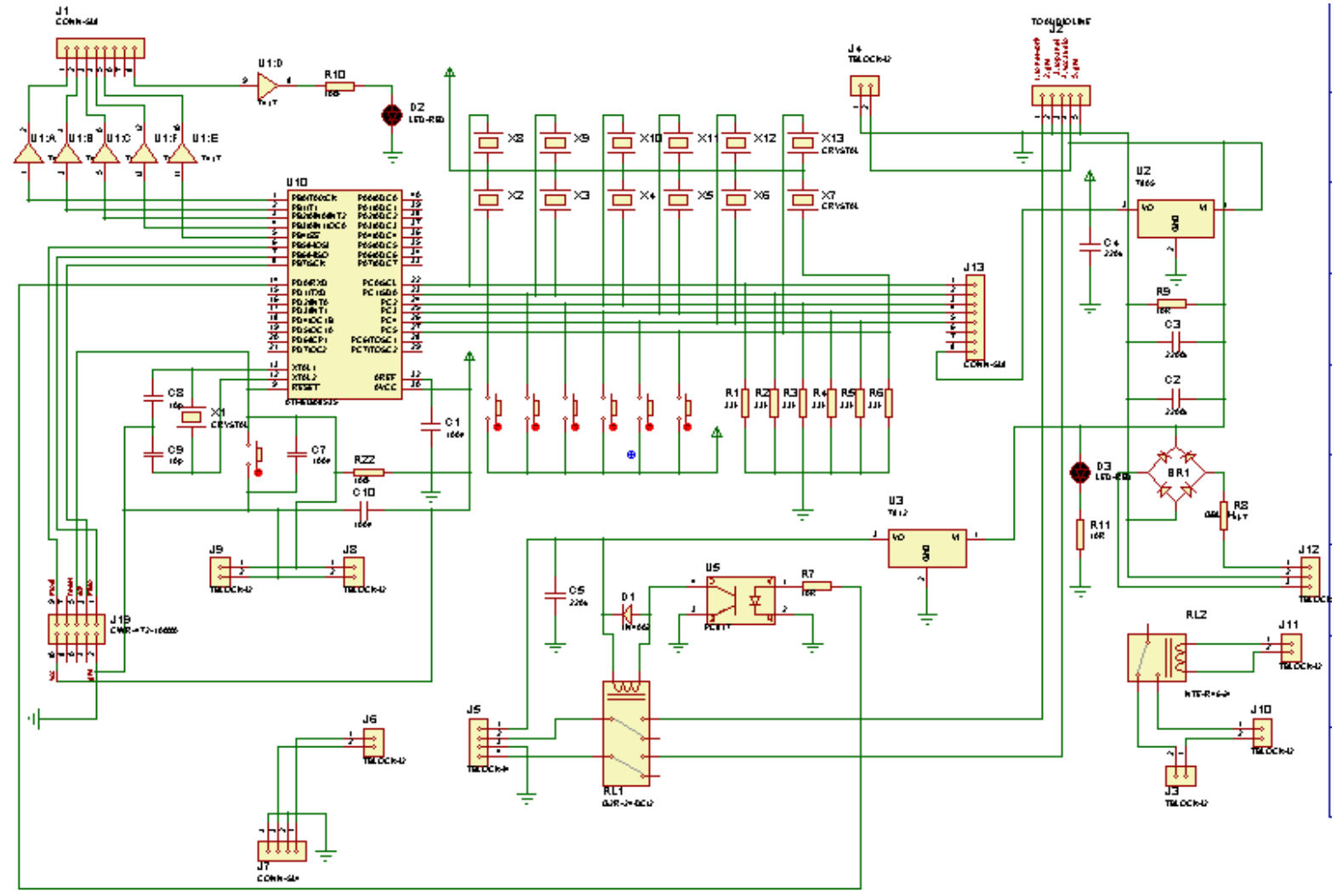

Gambar 8. Modul panel kontrol utama

\subsection{Rancangan BUS.}

Jalur bus menghubungkan panel kontrol dengan seluruh room controller terdiri dari jalur alamat yang terhubung dengan port-b ATmega8535, sedangkan jalur masukan terhubung 
dengan port-c ATmega8535, digunakan untuk saklar pemilih dalam komunikasi audio. Semua jalur bus mengontrol rangkaian secara paralel.

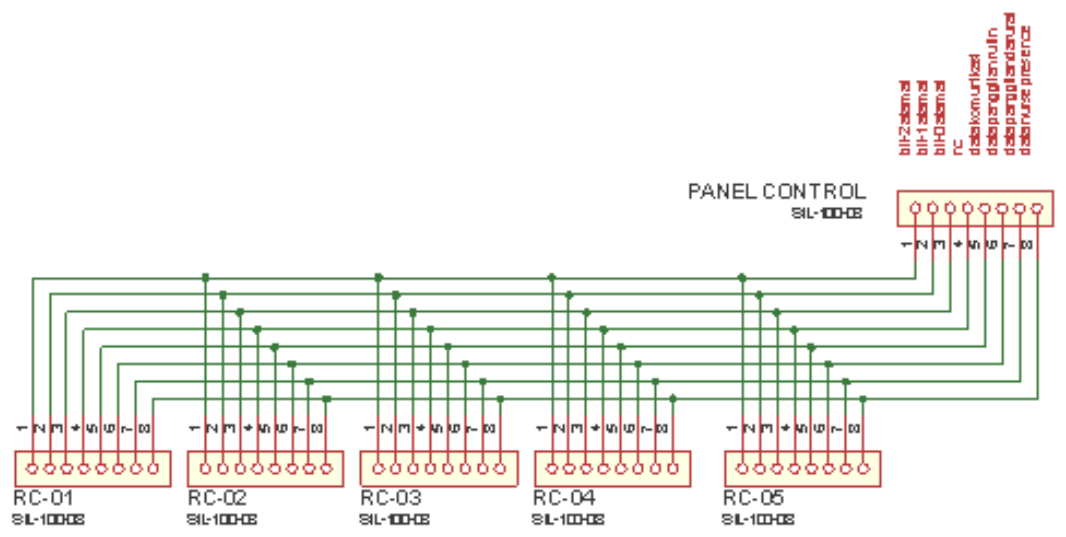

Gambar 9. Rancangan jalur bus

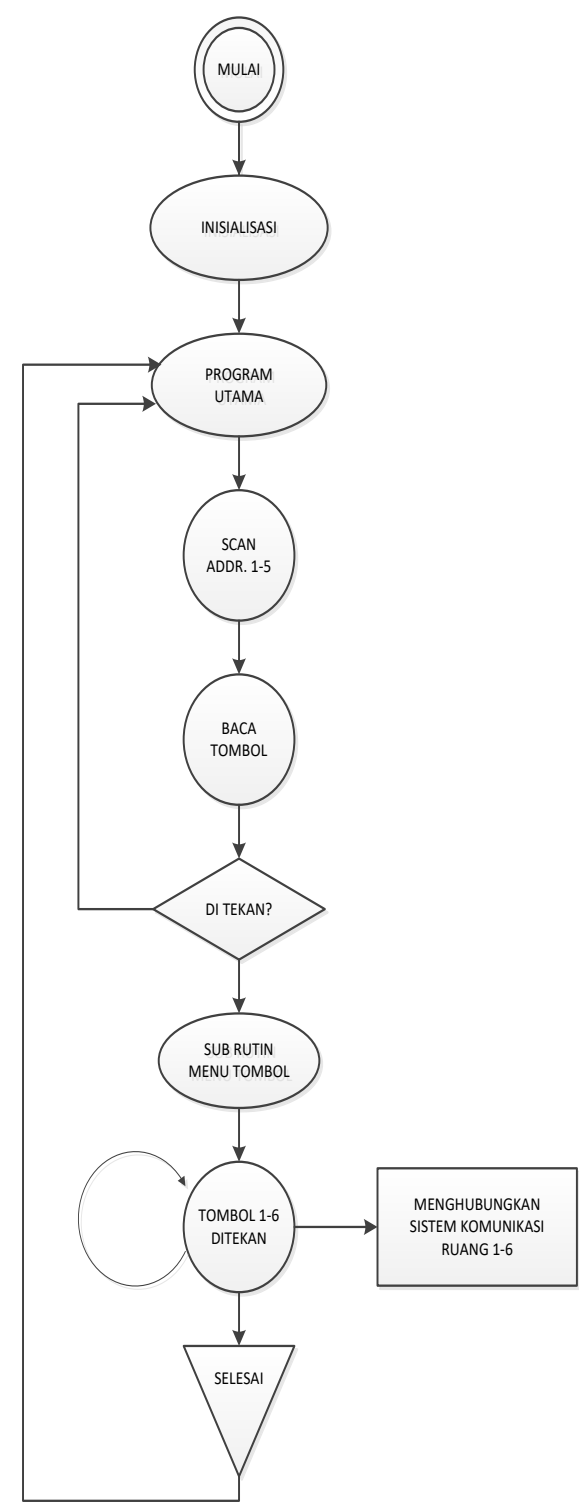

Gambar 10. Algoritma program mikrokontroler Atmega8535 
Dengan 3bit jalur bus alamat dan 3bit data bisa dikembangkan untuk mengontrol maksimal 7 titik room controller (ruangan) dan 7 data kondisi untuk setiap ruangan.

\subsection{Pemrograman mikrokontroler.}

Untuk pemrograman mikrokontroler, digunakan aplikasi AVR Studio dari Atmell sebuah program aplikasi yang dikembangkan sebagai Integrated Development Environment (IDE) yang di desain untuk mikrokontroler Atmel AVR. Bahasa pemrograman menggunakan Assembly. Struktur program dapat dibaca dengan algoritma pada gambar 10.

KETERANGAN:

Inisialisasi:

- mendefinisikan mikrokontroler yang digunakan

- mulai dari lokasi memori $\$ 0000$

\section{Program utama:}

\section{Sub rutin baca ruang:}

- out address room controller \#1

- out address room controller \#2

- out address room controller \#3

- out address room controller \#4

- out address room controller \#5

\section{Sub rutin baca tombol komunikasi:}

- Tombol-1 ditekan rcall room\#1

- Tombol-2 ditekan rcall room\#2

- Tombol-3 ditekan rcall room\#3

- Tombol-4 ditekan rcall room\#4

- Tombol-5 ditekan rcall room\#5

Kembali ke Program utama

\section{Room\#1:}

sambungkan ke ruang-1 selama tombol-1 ditekan; return

\section{Room\#2: $s$}

sambungkan ke ruang-2 selama tombol-2 ditekan; return

\section{Room\#3:}

sambungkan ke ruang-3 selama tombol-3 ditekan; return

\section{Room\#4:}

sambungkan ke ruang-4 selama tombol-4 ditekan; return

\section{Room\#5:}

sambungkan ke ruang- 5 selama tombol-5 ditekan; return.

\section{HASIL DAN PEMBAHASAN}

Setelah selesai dibuat purwarupa, dilakukan simulasi proses panggilan perangkat SPP dengan fitur komunikasi audio. Simulasi dilakukan karena perangkat tidak benar-benar dipasang di ruang rawat inap, karena masih berupa purwarupa.

Pengujian dilakukan dengan asumsi jarak terdekat antara pos perawat dengan pasien adalah 20 meter. Kemudian dilakukan perhitungan waktu pelayanan antara perangkat SPP 
dengan fitur komunikasi dan tanpa fitur komunikasi. Selain itu dihitung juga pemakaian daya listrik diantara kedua perangkat dengan jumlah titik panggil yang sama.

\subsection{Pengurangan proses kerja}

Secara proses terjadi pemangkasan proses kerja seperti pada diagram alir pada gambar 11, perawat tidak perlu dua kali mendatangi pasien sebagaimana ketika menggunakan perangkat SPP tanpa fitur komunikasi.

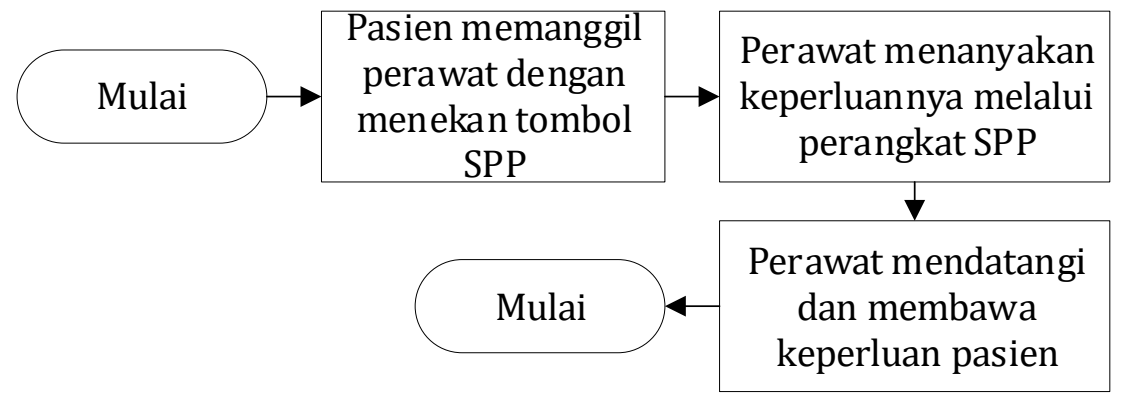

Gambar 11. Proses pelayanan dengan menggunakan perangkat SPP dengan fitur komunikasi

\subsection{Penghematan waktu}

Tabel 4 adalah perhitungan simulasi apabila menggunakan perangkat SPP Med-Friend yang digunakan di RS Meilia, perangkat ini tidak mempunyai fitur alat komunikasi audio.

Tabel 4. Perhitungan menggunakan perangkat SPP Med-Friend

\begin{tabular}{cllll}
\hline \multirow{2}{*}{ No } & \multicolumn{1}{c}{ Proses } & \multicolumn{3}{c}{ Waktu } \\
\cline { 3 - 5 } & & 20 Meter & 30 Meter & 40 Meter \\
\hline 1 & Panggilan & 3 detik & 3 detik & 3 detik \\
2 & Berjalan mendatangi pasien & 25 detik & 37.5 detik & 50 detik \\
3 & Berbicara dengan pasien & 15 detik & 15 detik & 15 detik \\
4 & Berjalan menuju pos perawat & 25 detik & 37.5 detik & 50 detik \\
5 & Mengambil kebutuhan pasien & 20 detik & 20 detik & 20 detik \\
6 & Berjalan menuju pasien & 25 detik & 37.5 detik & 50 detik \\
7 & Memasang cairan infus & 10 detik & 10 detik & 10 detik \\
8 & Kembali ke pos perawat & 25 detik & 37.5 detik & 50 detik \\
\hline & Jumlah & 148 detik & 198 detik & 248 detik
\end{tabular}

Tabel 5 adalah perhitungan simulasi apabila menggunakan perangkat SPP purwarupa yang dibuat, perangkat ini tidak mempunyai fitur alat komunikasi audio. Perhitungan dilakukan dengan menggunakan faktor variabel yang sama.

Tabel 5. Perhitungan simulasi menggunakan perangkat SPP purwarupa

\begin{tabular}{clccc}
\hline No & \multicolumn{1}{c}{ Proses } & Waktu \\
\hline 1 & Panggilan & 3 detik & 3 detik & 3 detik \\
2 & Berbicara dengan pasien & 15 detik & 15 detik & 15 detik \\
3 & Mengambil kebutuhan & 20 detik & 20 detik & 20 detik \\
& pasien & &
\end{tabular}




\begin{tabular}{llccc}
4 & Mendatangi pasien & 25 detik & 37.5 detik & 50 detik \\
5 & Memasang cairan infus & 10 detik & 10 detik & 10 detik \\
6 & Kembali ke pos perawat & 25 detik & 37.5 detik & 50 detik \\
\hline & Jumlah & 98 detik & 123 detik & 148 detik \\
\hline
\end{tabular}

Tabel 6. Resume penghematan waktu pelayanan.

\begin{tabular}{ccccc}
\hline 1 & Waktu & 50 detik & 75 detik & 100 detik \\
2 & Presentase & $34 \%$ & $38 \%$ & $40 \%$ \\
\hline
\end{tabular}

Pada grafik gambar 12 terlihat bahwa pada jarak 20 Meter terjadi penghematan 50 detik dan pada jarak 40 Meter terjadi penghematan waktu sebanyak 100 detik. Dapat disimpulkan semakin jauh jarak akan terjadi penghematan waktu yang lebih besar.

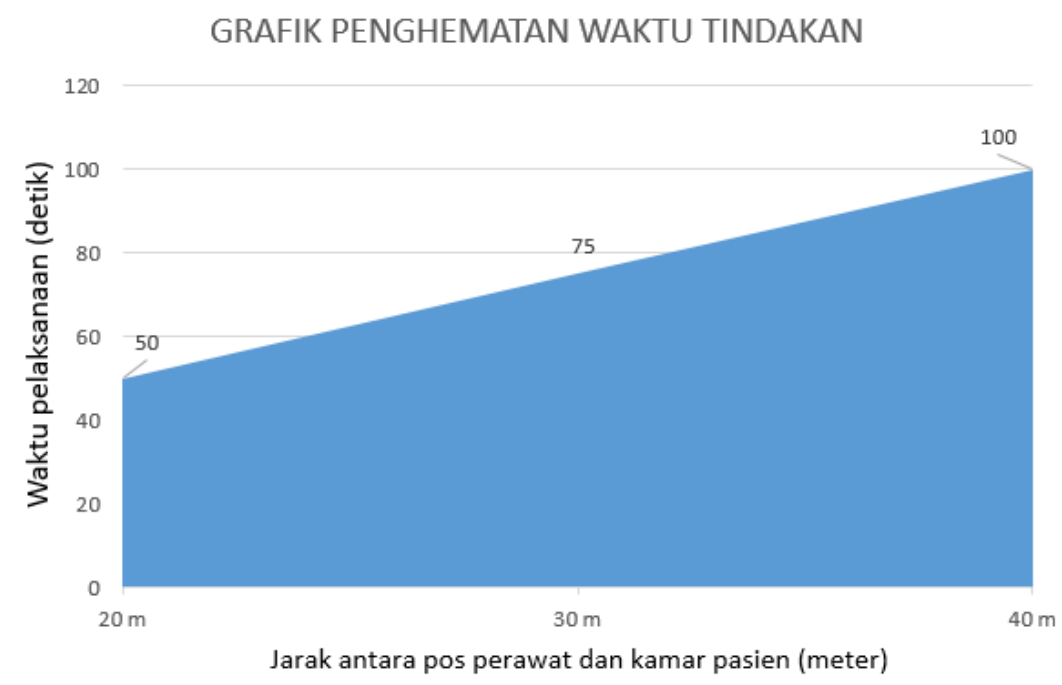

Gambar 12. Jarak antara pos perawat dan kamar pasien (meter).

3.3 Penghematan daya listrik.

Tabel 7. Perhitungan pemakaian daya listrik perangkat SPP MED-FRIEND.

\begin{tabular}{lllll}
\hline No & Proses & $\begin{array}{l}\text { Arus } \\
\text { Pemakaian }\end{array}$ & Daya & kWH/Bulan \\
& & & \\
\hline 1 & CPU/Personal Computer & 2.75 Ampere & 605 Watt & $435.6 \mathrm{kWH}$ \\
2 & Monitor & 0.8 Ampere & 176 Watt & $126.72 \mathrm{kWH}$ \\
3 & Modul di ruangan (5 & 1.5 Ampere & 330 Watt & $237.6 \mathrm{kWH}$ \\
& kamar) & 5.05 Ampere & 1111 Watt & $799.92 \mathrm{kWH}$ \\
\hline & Jumlah & & & 1.200 Rupiah \\
\hline & Tarik Listrik Industri & & 959.904 \\
\hline & Biaya listrik Perbulan & & Rupiah \\
\hline
\end{tabular}

Catatan: - Daya = Arus x Tegangan (220 V), kWH = Daya $\times$ Arus $\times 24$ Jam $\times 30$ hari

Tabel 8. Perhitungan pemakaian daya listrik perangkat SPP PURWARUPA.

\begin{tabular}{lllll}
\hline No & \multicolumn{1}{c}{ Proses } & \multicolumn{1}{c}{$\begin{array}{c}\text { Arus } \\
\text { Pemakaian }\end{array}$} & Daya & kWH/Bulan \\
& & & \\
\hline 1 & CPU/Personal Computer & 0.6 Ampere & 7.2 Watt & $5.184 \mathrm{kWH}$ \\
2 & Monitor & 0.15 Ampere & 1.8 Watt & $1.296 \mathrm{kWH}$
\end{tabular}




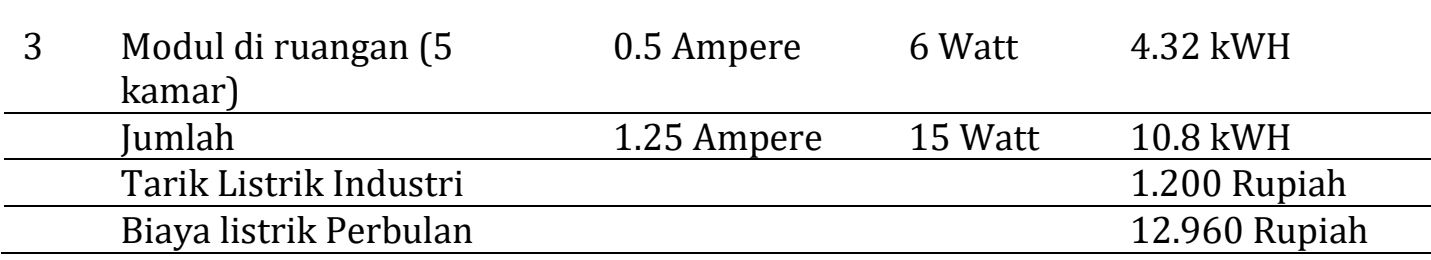

Catatan: - Daya = Arus x Tegangan (220 V), kWH = Daya $\times$ Arus $\times 24$ Jam x 30 hari

Tabel 9. Penghematan Listrik

\begin{tabular}{lll}
\hline 1 & $\begin{array}{l}\text { Pemakaian } \\
\text { daya }\end{array}$ & $789.12 \mathrm{kWH}$ \\
2 & Biaya listrik & 946.944 rupiah \\
3 & Presentase & $99 \%$ \\
\hline
\end{tabular}

3.4 Perbandingan dengan SPP acuan.

Setelah melakukan beberapa pengamatan, penilaian dan pengujian, secara umum dapat diperoleh perbandingan bahwa SPP purwarupa mempunyai beberapa kelebihan sebagai berikut:

- Penggunaan komponen elektronik lebih sedikit.

- Tidak menggunakan PC, sehingga menghemat pemakaian daya listrik dan biaya perawatan PC.

- Pengaturan alamat modul panggilan bisa dilakukan secara manual dengan mengatur DIP switch jadi tidak memerlukan komputer untuk merubah alamat.

- Secara harga sangat jauh di bawah harga kedua SPP acuan.

- Dalam proses komunikasi antara pasien dan perawat lebih efisien, karena perawat bisa terlebih dahulu berbicara dengan pasien terkait keperluannya.

Kekurangan:

- Tidak menggunakan PC jadi sulit melakukan manipulasi data.

- Tidak bisa terhubung dengan jaringan baik LAN maupun internet.

\section{SIMPULAN}

Perangkat SPP yang dibuat telah memenuhi ketentuan teknis Departemen Kesehatan, di antaranya adalah memiliki fitur/kemampuan, mempunyai modul pos rutin untuk memanggil dari tempat tidur pasien mempunyai modul pos darurat untuk memanggil dari toilet. mempunyai lampu dome di depan ruang rawat inap, sebagai penanda panggilan dari ruangan. Panggilan rutin dan darurat dibedakan dari warna lampu penanda dan suara alarm, mempunyai panel kontrol di pos perawat yang dapat menampilkan nomor/nama ruangan yang melakukan panggilan, mempunyai fitur komunikasi dua arah antara pasien dan perawat. Perangkat juga bisa merespon minimal empat panggilan sekaligus dalam waktu yang bersamaan, bahkan bisa merespon panggilan dari seluruh unit dalam satu jaringan sekaligus dalam waktu yang bersamaan. Perangkat SPP telah memenuhi kaidah yang ditetapkan pada saat membuat rancangan yaitu 4E (effective, efficient, economist, easy), Effective/efektif, karena perangkat SPP bisa beroperasi sesuai fungsinya dan memenuhi ketentuan regulasi yang berlaku. Efficient/efisien, karena perangkat SPP menggunakan sumber daya listrik yang lebih irit, diantaranya karena tidak menggunakan komputer sebagai panel kontrol. Dan menghemat waktu pelayanan karena adanya fitur komunikasi. Economist/ekonomis, karena perangkat SPP dibuat dengan menggunakan seminimal mungkin komponen dan menggunakan komponen yang mudah didapatkan dan murah di pasaran. Easy/mudah, perangkat SPP dirancang sedemikian rupa, 
sehingga setiap unit/modul bisa dilakukan uji fungsi secara mandiri tanpa harus terhubung dengan jaringan sistem, untuk modul yang mempunyai alamat (address) penyetelannya mudah tanpa harus memprogram dengan menggunakan komputer tetapi cukup mengatur posisi DIP switch. Yang perlu dipertimbangkan terkait pengembangan sistem. Penambahan fasilitas perekaman data history kejadian dalam periode tertentu, sehingga apabila ditemukan suatu masalah bisa dilacak dari data history. Penambahan antar muka yang memungkinkan perangkat bisa dihubungkan dengan jaringan internet sehingga bisa di pantau atau dikendalikan dari tempat lain dengan mudah melalui jaringan internet. Rancangan ini pastilah bukan yang terbaik, tetapi harapan penulis, dengan rancangan bisa memantik ide untuk menciptakan dan membuat perangkat SPP yang lebih baik lagi. Penulis senantiasa terbuka untuk menerima kritik dan saran yang bersifat membangun agar bisa menjadi acuan untuk membuat tulisan dimasa mendatang. Sebagai manusia tentunya penulis tidak akan terlepas dari kesalahan, dan kesempurnaan hanya milik Allah semata.

\section{DAFTAR PUSTAKA}

[1] Badan Pengembangan dan Pembinaan Bahasa, Kemdikbud, "Kamus Besar Bahasa Indonesia (KBBI)," 2019. [Online]. Available: https://kbbi.web.id/rancang-2. [Diakses Desember 2020].

[2] J. F. G. D. A. R. B. Alan Dix, Human-Cmputer Interaction, Third Edition, Harlow, England: Pearson Education Limited, 2004.

[3] Cambridge University, “Cambridge Dictionary,” 2019. [Online].

[4] Departemen Kesehatan, “Pedoman Teknis Fasilitas Rumah Sakit kelas B,” Jakarta, 2010.

[5] R. Cahyaningtyas, "Modul Teori Bahasa dan Automata," Jakarta, 2012.

[6] GIRA, “Nurse Call System Plus Overview,” Dahlienstrabe, 2012.

[7] P. B. M. M. W. Roby, "Bel pemanggil perawat rumah sakit berbasis wireless menggunakan android," JUTEI Volume 1 No.1 ISSN 2579-3675, e-ISSN 2579-5538D01 10.21460/jutei.2017.11.11, 2017.

[8] T. Alfianur, "Digital Repository @ Universitas Muhammadiyah Yogyakarta," 2014. [Online]. Available: http://thesis.umy.ac.id/index.php?opo=bibliography\&id=51329.

[9] Microsoft.USA 2007.

[10] B. Padmanaban, “Unified Modeling Language (UML) Overview," 2012.

[11] Y. Suyanto, "Perancangan Sistem Digital," 2009.

[12] A. H. Asri, "Pengenalan Elektronika dan Komponen Elektronika," Bandung, 2014.

[13] T. Elektronika, “Teknik Elektronika," 2020. [Online]. Available: Pengertian Transistor dan Jenis-jenis Transistor.

[14] Syahrul, Mikrokontroler AVR Atmega8535, Bandung: Informatika, 2012.

[15] Republik Indonesia, Undang-undang No. 44 Tahun 2009, Pemerintah Republik Indonesia, 2009.

[16] Atmel, “ATmega 8535," Atmel Corporation, San Jose, USA, 2017. 